\title{
Hyphal Tip Bursting in Mucor rouxii: Antagonistic Effects of Calcium Ions and Acid
}

\author{
By J. M. DOW* AND P. H. RUBERY \\ Department of Biochemistry, University of Cambridge, \\ Cambridge $C B 2$ I $Q W$
}

(Received 25 April 1975; revised 3 I July 1975)

\section{INTRODUCTION}

The problem of the apical extension growth of fungal hyphae has been approached by investigating the bursting of hyphal tips in response to various experimental treatments. Tip bursting was considered to be a consequence of disturbing a delicate balance between loosening or plasticization of the wall in the tip region and simultaneous deposition of new wall material in the same zone (Bartnicki-Garcia \& Lippman, 1972a). Circumstantial evidence from such experiments has been used to support the view that the proposed plasticization may be due to localized enzymic lysis of existing wall polymers (BartnickiGarcia \& Lippman, $1972 b$ ). Similar models have been suggested for the extension of higher plant cells but in this case, there is evidence against the participation of enzymes which hydrolyse either the cellulose fibrils (Ruesink, I969) or the matrix polysaccharides of the cell wall (Evans, 1974).

We investigated the effects of both osmotic protection and $\mathrm{Ca}^{2+}$ ions on the bursting of Mucor rouxii hyphal tips at low pH. It is difficult to reconcile our data with a role for polysaccharide hydrolases as one component of the balance which allows hyphal extension to occur whilst maintaining the structural integrity of the apex.

\section{METHODS}

All chemicals were analytical grade where possible; the polyethylene glycol (PEG) had a molecular weight of 400 . Mucor rouxii strain 68072 was obtained from the Commonwealth Mycological Institute, Kew, and maintained on potato-dextrose-agar medium. Fungal cultures were grown in $60 \mathrm{~mm}$ diameter Petri dishes on $10 \mathrm{ml}$ of a dilute, sterile medium containing Difco yeast extract $(0.19 \mathrm{~g} / \mathrm{l})$, Difco Bactopeptone $(0.63 \mathrm{~g} / \mathrm{l})$ and D-glucose $(\mathrm{I} \cdot 25 \mathrm{~g} / \mathrm{l})$, made up with glass-distilled water and solidified with $2 \%$ Difco-Agar (Noble). The nutrient components represent a I6-fold dilution of the medium used by BartnickiGarcia \& Nickerson ( $1962 a$ ). The plates were inoculated in the centre with a suspension of sporangiospores in distilled water and grown for $\mathrm{I} 3$ to $17 \mathrm{~h}$ at $28{ }^{\circ} \mathrm{C}$ in the dark. The effects of test solutions $(5 \mathrm{ml})$ on the bursting of hyphal tips were observed at room temperature with the aid of a Nikon stereoscopic binocular microscope. In some experiments, colonies were pretreated with $0.2 \mathrm{ml}$ of $0.25 \mathrm{M}-\mathrm{CaCl}_{2}$ before flooding with $5 \mathrm{ml}$ test solution. Burst tips were easily recognized by the extrusion of a globule of cytoplasm. Note that even with a maximal response (designated as 'extensive tip bursting'), only a proportion of the tips burst since the mycelial hyphae are branched and non-septate;

* Present address: University of Leeds, Department of Plant Sciences, Leeds LS2 9JT. 
presumably a single burst within connected tips would release the turgor pressure. The bursting pattern is similar to that observed by Bartnicki-Garcia \& Lippman (1972a) where the leading hypha or a side branch (but rarely both) burst.

\section{RESULTS AND DISCUSSION}

We have found, in agreement with Bartnicki-Garcia \& Lippman (1972a), that exposure

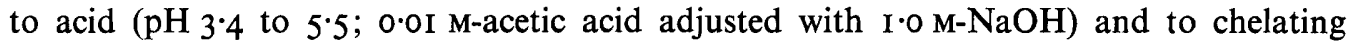
agents (0.0I M-EDTA pH 7.0 and 0.0I M-sodium hexametaphosphate $\mathrm{pH} 5.7$ to 6.8 ) both caused extensive bursting of hyphal tips within a few seconds of flooding. Exposure to high $\mathrm{pH}(\mathrm{NaOH}, 0.0$ I to I00 $\mathrm{mm}$; $\mathrm{pH} 9$ to 13$)$ or to distilled water did not lead to bursting. We extended these observations to investigate the effects of both osmotic protection and $\mathrm{Ca}^{2+}$ ions on the response of hyphal tips to low $\mathrm{pH}$.

\section{The effects of acid and polyethylene glycol}

In the absence of PEG, the bursting of tips in response to acid occurred over the range $\mathrm{pH}_{3.4}$ (maximum bursting) to $\mathrm{pH} 5.0$ (no bursting). The bursting was rapid, occurring within $3 \mathrm{~s}$ of flooding. However, inclusion of $0.15 \mathrm{M}-\mathrm{PEG}$ in the flooding medium prevented bursting at $\mathrm{pH}_{4} .5$. Presumably, the osmotic protection afforded by the non-penetrating PEG prevented rupture of the acid-weakened wall. At $\mathrm{pH}_{4} \cdot \mathrm{O}$ and $\mathrm{pH}_{3} \cdot 6$, bursting was less extensive and less rapid than without PEG, but at $\mathrm{pH} 3.4$, extensive bursting again occurred within $3 \mathrm{~s}$.

In a separate experiment, colonies were exposed for $\mathrm{IO} s$ to an acidic hypertonic medium

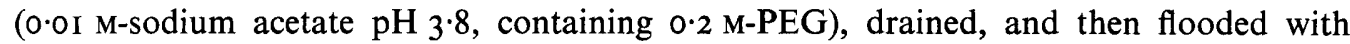
either an acidic hypotonic medium (O.0 I M-sodium acetate $\mathrm{pH}_{3} .8$ ) when the tips burst within IO s, or with distilled water when the tips remained intact. Transfer from distilled water to $0.0 \mathrm{I} \mathrm{M}$-sodium acetate $\mathrm{pH} 3.8$ resulted in extensive bursting within Io s. These observations indicate that no irreversible weakening of the wall had occurred during initial exposure to the acidic hypertonic medium. The data are difficult to reconcile with the operation of lytic enzymes having acidic $\mathrm{pH}$ optima that are located in the cell wall at the hyphal tip unless such an enzymic lysis were reversibly inhibited by the osmotic protectant.

\section{The effect of $\mathrm{Ca}^{2+}$ pretreatment on the acid-bursting response}

Exposure to $\mathrm{CaCl}_{2}$ solutions leads to swelling of the apical region and occasionally to bursting. This effect has been interpreted in terms of a $\mathrm{Ca}^{2+}$-mediated increase in wall lytic activity relative to wall deposition (Bartnicki-Garcia \& Lippman, 1972a). We studied the effect of pretreating colonies with $0.2 \mathrm{ml}$ of $0.25 \mathrm{M}-\mathrm{CaCl}_{2}$ for varying times followed by flooding with $0.0 \mathrm{I} \mathrm{M}$-sodium acetate $\mathrm{pH} 4.0$. The time of initiation of bursting was scored (Fig. I). The $\mathrm{Ca}^{2+}$ pretreatment delayed but did not prevent the initiation of bursting by acid, which was nevertheless always extensive. Flooding with distilled water after pretreatment with $\mathrm{CaCl}_{2}$ caused no bursting. These observations are again difficult to reconcile with a $\mathrm{Ca}^{2+}$-stimulated cell wall lytic process that has enhanced activity at low $\mathrm{pH}$. Rather, the $\mathrm{H}^{+}$ions and $\mathrm{Ca}^{2+}$ ions appear to be working in opposition.

Our knowledge of the detailed molecular composition and architecture of fungal walls is limited, although the polymers of $M$. rouxii walls are quite well characterized (BartnickiGarcia, I968; Bartnicki-Garcia \& Reyes, I968a,b). Mucor rouxii hyphal walls contain polymers capable of conferring both form and tensile strength, chitin and chitosan 


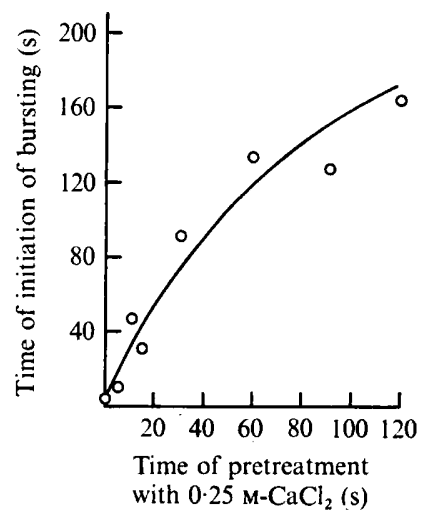

Fig. I. Effect of pretreatment with $\mathrm{Ca}^{2+}$ ions on the time of initiation of bursting on flooding with acid $\left(\mathrm{pH}_{4}{ }^{\circ}\right)$.

(Bartnicki-Garcia \& Nickerson, 1962b), and polymers which may form a matrix in which the fibrillar components of the wall are embedded. The integrity of the wall at the hyphal tip may depend not only on the distribution and orientation of the fibrils, but also on the properties of the matrix material which contains the acidic polymers mucoran and mucoric acid (Bartnicki-Garcia \& Reyes, I968a, $b$; Bartnicki-Garcia \& Lindberg, 1972).

Although it is possible to account for our results on an ad hoc basis by a lytic theory of wall plasticization, a simpler explanation may be that the reversible and antagonistic effects of $\mathrm{H}^{+}$and $\mathrm{Ca}^{2+}$ ions on the integrity of hyphal tips are due to a modification of the physical properties of the matrix wall polymers rather than to the cleavage of covalent bonds. In this connexion, there is some heuristic value in a comparison with the primary cell walls of higher plants where the acidic pectic polysaccharides exist mainly as the $\mathrm{Ca}^{2+}$ salt and constitute a major proportion of the matrix. Cell extension is inhibited by exposure to $\mathrm{Ca}^{2+}$ ions which leads to a hardening of the cell wall (Ray \& Baker, 1965) and is promoted by $\mathrm{H}^{+}$ions (Davies, 1973). In vitro $\mathrm{Ca}^{2+}$ enhances the viscosity of pectin solutions, whereas acidification of the calcium pectate makes the solutions more fluid. Ultimately, $\mathrm{Ca}^{2+}$ causes pectin solutions to form gels which can be dissolved by acids and chelating agents (P. H. Rubery and A. R. Sheldrake, unpublished observations). In a similar way, mucoran isolated from cell walls by the method of Bartnicki-Garcia \& Reyes ( $1968 b$ ) forms a precipitate on addition of $\mathrm{Ca}^{2+}$ which can be dissolved in acetic acid. High concentrations of $\mathrm{HCl}$ alone cause the polymer to precipitate.

If the integrity of the hyphal apex depends on some property of the matrix related to the viscous behaviour of mucoran solutions, then factors leading to an increase in fluidity, such as the action of acids and chelating agents on the $\mathrm{Ca}^{2+}$ salt, might be expected to allow tip disintegration by osmotic bursting, whereas treatments which decrease the fluidity of the matrix, such as exposure to $\mathrm{Ca}^{2+}$, might produce tips more refractory to bursting.

It is known that deposition of both matrix and fibrils is essential to maintain tip integrity, since inhibition of chitin synthesis leads to bursting (Bartnicki-Garcia \& Lippman, 1972b), but our data focus attention on the possibility that interaction of $\mathrm{Ca}^{2+}$ and $\mathrm{H}^{+}$ions, in modifying the viscous properties of the matrix acidic polymers, may be one element in the maintenance of a plastic region at the apex to allow extension in response to turgor pressure. Such effects could be of general importance in those fungi with acidic polysaccharides in their hyphal walls. 
We are grateful to Christine Clark for valuable technical assistance. This work was done during the tenure of an M.R.C. scholarship by J.M.D.

\section{REFERENCES}

Bartnicki-Garcia, S. (1968). Cell wall chemistry, morphogenesis and taxonomy of fungi. Annual Review of Microbiology 22, 88-108.

BartnICKI-GARCIA, S. \& LindBerg, B. (1972). Partial characterization of Mucoran: the glucuronomannan component. Carbohydrate Research 23, 75-85.

Bartnicki-GarCia, S. \& Lippman, E. (I972 $a$ ). The bursting tendency of hyphal tips of fungi: presumptive evidence for a delicate balance between wall synthesis and wall lysis in apical growth. Journal of General Microbiology 73, 487-500.

BartNiCKI-GARCIA, S. \& LipPMAN, E. (1972 $b$ ). Inhibition of Mucor rouxii by polyoxin D: effects on chitin synthetase and morphological development. Journal of General Microbiology 71, 301-309.

BarTNICKI-GARCIA, S. \& Nickerson, W. J. (1962a). Induction of yeastlike development by carbon dioxide. Journal of Bacteriology 84, 829-840.

BARTNICKI-GARCIA, S. \& NICKERSON, W. J. (I962 $b$ ). Isolation, composition, and structure of cell walls of filamentous and yeastlike forms of Mucor rouxii. Biochimica et biophysica acta 58, $102-119$.

BartNiCKI-Garcia, S. \& ReYeS, E. (I968a). Chemical composition of sporangiophore walls of Mucor rouxii. Biochimica et biophysica acta $\mathbf{1 6 5}, 32-42$.

Bartnicki-Garcia, S. \& ReYes, E. (I968b). Polyuronides in the cell walls of Mucor rouxii. Biochimica et biophysica acta 170, 54-62.

Davies, P. J. (1973). Current theories on the mode of action of auxin. Botanical Review 39, 139-17I.

Evans, M. L. (1974). Evidence against the involvement of galactosidase or glucosidase in auxin- or acid-stimulated growth. Plant Physiology 54, 213-215.

RAY, P. M. \& BAKeR, D. B. (1965). The effect of auxin on synthesis of oat coleoptile cell wall constituents. Plant Physiology 40, 353-368.

Ruesink, A. W. (1969). Polysaccharidases and the control of cell wall elongation. Planta 89, 95-107. 